\title{
Another pandemic in the making
}

As I write this, we will have had a State of Disaster in South Africa for 20 months. The initial reason for its imposition was the COVID19 pandemic that led to extraordinary measures to try to mitigate the effect of the virus on the country. Our borders closed, we were confined to our homes (those of us who could stay at home), the sale of alcohol and cigarettes was banned and a curfew was imposed. Sadly, these and subsequent measures did little to stay the course of the virus - we have had the worst outbreak in Africa, and continue to be the worst-affected country on the continent.

What is very clear is that South Africa is now facing a mental health emergency. ${ }^{[1,2]}$ This is a result of the unemployment crisis, the inequality crisis, the gender-based violence crisis and the poverty crisis. Each one of these has been massively exacerbated by the impact of COVID-19 - and not so much the impact of the virus itself, but the measures imposed on us by government, through the Command Council set up in the State of Disaster.

October is Mental Health Month, and on 10 October 2021, the South African Depression and Anxiety Group (SADAG) released a shocking set of figures. Between January and September 2021, SADAG received 466607 calls, a staggering $47 \%$ increase on the same period in 2020. The suicide helpline alone received 85516 calls in the past 9 months - more than 2000 calls a day.

As mental health experts know, there are many factors that impact on mental health, some of which are individual. But equally, a significant amount of the variation is explained by the environment. The NIDS-CRAM (National Income Dynamics Study - Coronavirus Rapid Mobile Survey) survey ${ }^{[2]}$ shows that $52 \%$ of those surveyed have experienced significant depressive symptoms since the start of the pandemic. This is not a group of depressed individuals, but different people moving in and out of the depressed mood category. The authors ascribe this to the continuing cycle of unemployment, shifting states of hunger, and changes in mood as a result. People are no longer able to fulfil their basic needs - stable housing, employment, and food on the table. Hunger in particular is associated with poor mental health.

As pointed out in an editorial by Mark Heywood in the Daily Maverick ${ }^{[1]}$ the end of the third wave is showing signs that for the monied, the privileged and the homed, life is starting to return to normal. People are looking forward to Christmas and holidays. But for the majority of our fellow citizens, this is not their life. This situation is the consequence of what many, including Mark Heywood, are calling a 'manufactured virus' - inequality and poverty.

But while the government seems intent on continuing to hold us all in a State of Disaster and rule us by decree from the Coronavirus
Command Council, there is little or nothing being done to address this looming pandemic of mental ill health and underlying poverty. The toll on people is incalculable - the toll on our society at least that of COVID-19. Budgets for mental healthcare are being cut, as seen in reports this week from KwaZulu-Natal, where a mental health report describes Durban and Coastal Mental Health (DCMH) as having 'compromised quality of care, abuse, neglect and other human rights violations of service users. ${ }^{[3]}$ An Independent Investigative Team report, commissioned by the KwaZulu-Natal Head of Department and submitted on 10 September 2021, has found shocking neglect of basic governance, abuse, neglect and human rights violations of service users, self-enrichment by members of the Board and their associated management, misappropriation of DCMH finances, and use of COVID-19 as a cover for irregularities and mismanagement.

Where are mental health patients in all this? Where are the depressed and suicidal in our society? Are we really going to continue to walk past the homeless under bridges, or, as in the little Garden Route town I live in, sleeping through our bitterly cold winter on the steps of the local library? Government needs to be held to account. The State of Disaster needs to be ended. Parliamentary oversight must be reinstated. All aspects of the pandemic need to be on the radar, and the devastating effects of our constant lockdowns need to be examined minutely and addressed. Poverty is a pandemic, and poor mental health is a shattering consequence of this.

\section{Bridget Farham \\ Editor \\ ugqirha@iafrica.com}

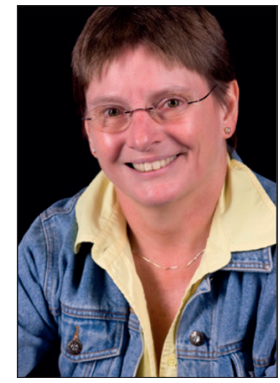

1. Heywood M. South Africa's mental health epidemic: Love don't live here anymore. Daily Maverick, 12 October 2021. https://www.dailymaverick.co.za/article/2021-10-12-south-africas-mental-healthepidemic-love-dont-live-here-anymore/?utm_medium=email\&utm_campaign=Maverick $\% 20$ Citizen\%20Tuesday $\% 2012 \% 20$ October\% 202021 \&utm_content=Maverick $\% 20$ averick $\% 2$ Citizen\% 2020 Citizen $\% 2$ Tuesday $\% 2012 \% 20$ October\% $202021+$ CID_c6cae 8152 dec 81 e 9 ee $498 \mathrm{fb} 8$ aff 0981 \&utm source=Touch ase Prow

2. National Income Dynamics Study (NIDS) - Coronavirus Rapid Mobile Survey (CRAM). Synthesi report: NIDS-CRAM wave 5. https://cramsurvey.org/wp-content/uploads/2021/07/1.-Spaull-N. Daniels-R.-C-et-al.-2021-NIDS-CRAM-Wave-5-Synthesis-Report.pdf (accessed 15 October 2021

3. Pikolo Z. Durban and Coastal Mental Health possibly the next Life Esidimeni tragedy in the making. Daily Maverick, 10 October 2021. https://www.dailymaverick.co.za/article/2021-10-10-durban-and-coastalmental-health-possibly-the-next-life-esidimeni-tragedy-in-the-making/ (accessed 15 October 2021).

S Afr Med J 2021;111(11):1029. https://doi.org/10.7196/SAMJ.2021.v111i11.16230 